\title{
Histological and Histochemical Studies on the Prenatal Development of Testis in Goat (Capra hircus)
}

\author{
Estudios Histológicos e Histoquímicos del Desarrollo Prenatal del Testículo de Cabra (Capra hircus)
}

\author{
M. M. Farooqui; Chandrapal, Archana \& Ajay Prakash
}

FAROOQUI, M. M. CHANDRAPAL, ARCHANA \& PRAKASH, A. Histological and histochemical studies on the prenatal development of testis in goat (Capra hircus). Int. J. Morphol., 30(4):1408-1421, 2012.

SUMMARY: The study has been conducted on the prenatal development of testis on 70 goat embryo/foeti, categorized into group-I (0-30 days), Group-II (31-60 days), Group-III (61-90 days), Group-IV (91-120 days) and group V (121 days-till birth), having 14 embryos/ foeti in each group. The genital ridge was observed at 23 days of gestation. It contained an accumulation of mesenchymal cells, immature RBC's, differentiating fibroblasts and primordial germ cells. The formation of sex cords was evidenced on $44^{\text {th }}$ day of gestation. It contained small mesenchymal cells and large cells arranged in a chain like manner. The convolution of the sex cords started between 61-90 days of gestation, which increased with the increase in the gestation period and at 125 day of gestation few sex cords attained the form of reverse question mark. The sustentocytes (Sertoli cells) were observed among the small cells of sex cords at $56^{\text {th }}$ day of gestation. The tunica albuginia appeared just beneath the germinal epithelium at $44^{\text {th }}$ day of gestation. It consisted of $2-4$ layers of mesenchymal cells, fibroblasts and small capillaries. The thickness of tunica albuginia increased with the increase in the age of foetus and between 6190 days of gestation, the outer thick fibrous and inner thin vascular layer could be demarcated separately. Few mesenchymal cells start differentiating into interstititial endocrine cells (Leydig cells) located in the interstitial spaces at $44^{\text {th }}$ day of gestation.

KEY WORDS: Testis; Prenatal development; Goat.

\section{INTRODUCTION}

Testicles are the important organ for the production of spermatozoa and testosterone. Literature is available on the postnatal development of testis in goat (Baishya et al., 1987, Gupta, 1989, Islam et al., 2002, Archana, 2006), but very little work has been conducted on the prenatal development of testis (Singh et al., 1979). Therefore an attempt has been made to record the sequential account of structural changes in the development of testis in prenatal goat.

\section{MATERIAL AND METHOD}

A study was conducted on the 70 embryo/ foeti ranged from 23 days to full term collected from the gravid uteri of apparently healthy goat, obtained from local abattoir. Each foetus was measured for its crown rump length in centimeters with the help of nylon tape (Harvey, 1959) and weighed in grams on analytical balance. The approximate age was computed according to the formula derived by Singh et al. after interpolation of the formula given by Hugget \& Widdas (1951) in mammals. These embryo/foeti were divided into five groups.

\begin{tabular}{llll}
\hline S. & Group & Age & Weight of foetus (g) \\
\hline 1. & Group-I & 0-30days & --- \\
2. & Group-II & 31-60 days & 0.86 to 18.9 \\
3. & Group- III & 61-90 days & 56 to 200.0 \\
4. & Group- IV & 91-120 days & 284 to 435.8 \\
5. & Group- V & 121-till term & 675 to 1720.34 \\
\hline
\end{tabular}

The sex of foeti was determined by the appearance of genital tubercle in the form of epithelial tag, genital swelling, anogenital raphae up-to mid stage of II group. In other groups the sex was identified by the development of penis and scrotal sac. The ventral abdominal incision was given to remove the testis. The small pieces of the tissues from different representative areas were collected from testis and fixed in 10 percent neutral buffered formalin. The tissues were processed by routine paraffine embedding technique and were sectioned at 5-6 $\mu \mathrm{m}$. The sections were stained with $\mathrm{H} \&$ 
E for general histo-architecture (Luna, 1968), Mallory's triple stain, Crossman's modification (1937) for collagen fibers, Wilder's reticulin stain (Luna) for reticular fibers, Weigert's Resorcin Fuchsin stain (Luna) for elastic fibers demonstration. For the demonstration of glycogen, mucopolysaccherides, lipid, DNA, Acid and Alkaline phosphatase enzymes PAS stain with and without saliva (Davenport, 1960), AMPS reaction, Sudan Black-B stain (Luna), Gomori's calcium method (Bancroft \& Stevens, 1971) and Gomori's lead method (Bancroft \& Stevens) were performed. Micrometry was done with the help of oculometer. The data was subjected to the statistical analysis for interpretation.

\section{RESULTS AND DISCUSSION}

At 23 days of gestation, the genital ridge was composed of mesenchymal cells, immature RBCs, differentiating fibroblasts and primordial germ cells (PGC) (Fig.1) as reported by Singh et al. in goat embryos at same stage of gestation. Large cells known as primordial germ cells in pig (Patten, 1948), goat (Singh et al.) and human beings (Copenhaver, 1978) were observed between the

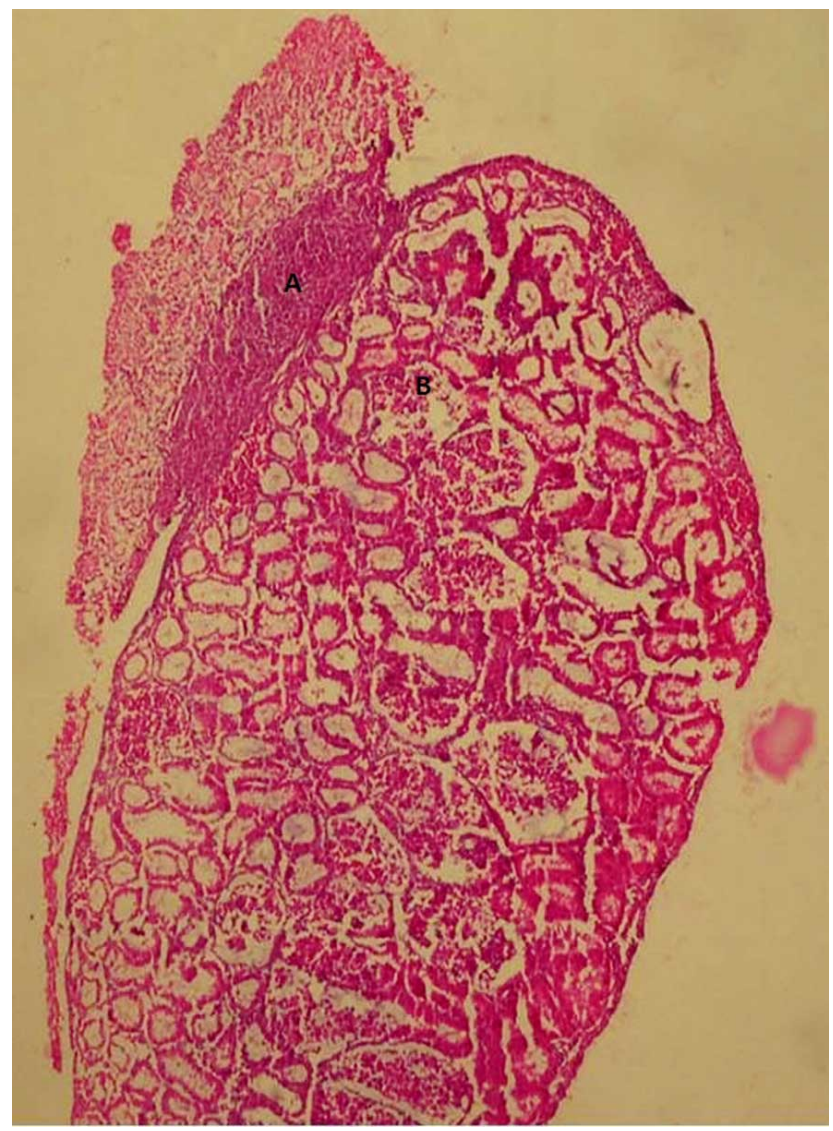

Fig. 1. Photomicrograph of mesonephros from a 23 day old goat embryo showing genital ridge (A) and mesonephros (B). H \& E x 40 mesenchymal cells in the present study. These cells were very few in number and measured on an average $8.56+$ $2.423 \mathrm{~mm}$ in diameter. The cytoplasm of primordial germ cells was acidophilic in nature and mildly PAS reactive. Johnson et al. (1970) observed positive reaction for PAS in these cells of genital ridge in domestic animals. Nuclei of these cells were vesicular in nature and measured $5.25+$ $3.486 \mathrm{~mm}$ in diameter. Nuclear chromatin was concentrating more towards periphery. Small cells (Mesenchymal cells) were spherical or oval in shape and measured 3.02 to $4.53 \mathrm{~mm}$ in diameter. The cytoplasm of such cells was more eosinophilic than PGC (large cells). Small cells showed slight to moderate PAS reaction in contrast to Johnson et al., who reported negative reaction for PAS in domestic animals. Nuclei of these cells were spherical in shape and measured 2 to $3 \mathrm{~mm}$ in diameter. These nuclei contained finely granulated, evenly distributed nuclear chromatin and centrally placed nucleolus (Fig.2).

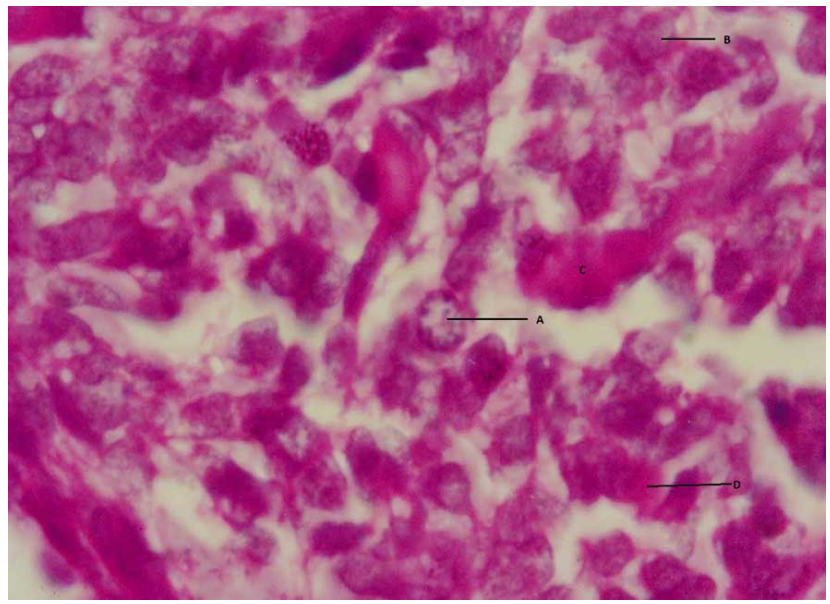

Fig. 2. Photomicrograph of genital ridge showing the primordial germ cell (A), small cells (B), blood vessels (C) and differentiating erythrocytes (D). H \& E x 1000.

Few mesenchymal cells were spindle shaped and had slightly eosinophilic cytoplasm and densely stained nuclei. These cells, in the present study, were designated as differentiating fibroblasts. Few immature RBCs were also encountered among the mesenchymal cells (Fig. 2). Some small cells exhibited mitotic activities. Inter cellular matrix was foamy in appearance and had a acidophilic nature.

Germinal epithelium. At $23^{\text {th }}$ day of gestation, a layer of simple squamous epithelium was present covering the underlying genital ridge at both the ends of mesonephros. Singh et al., also reported similar findings at this stage.

In group II ( $31-60$ days), at $44^{\text {th }}$ day of gestation, the simple squamous epithelium changed to low cuboidal except towards the mesothelium of mesonephros (Fig.3). 


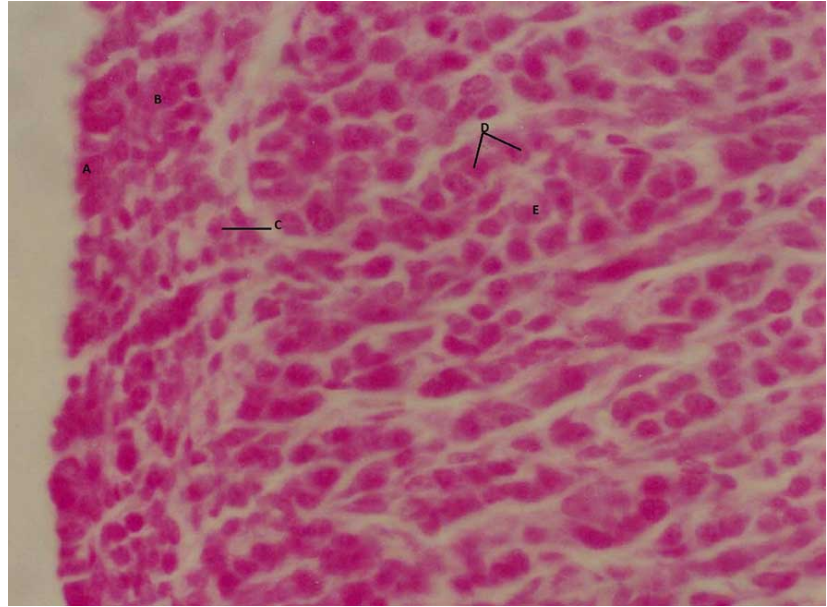

Fig. 3. Photomicrograph of the testis from a 44 day old goat foetus showing the germinal epithelium (A), capsule (B), septula testis (C), small cells (D) and sex cords (E). H \& E x 400.

Cytoplasm of these epithelial cells showed moderate reaction for acid mucopolysaccharides (Fig. 4). The basement membrane exhibited intense reaction for acid mucopolysaccharides and PAS. Spherical nuclei contained evenly distributed fine chromatin. Cells of the germinal epithelium were not continuous. In between the germinal epithelial cells, large primordial germ cells were also encountered.

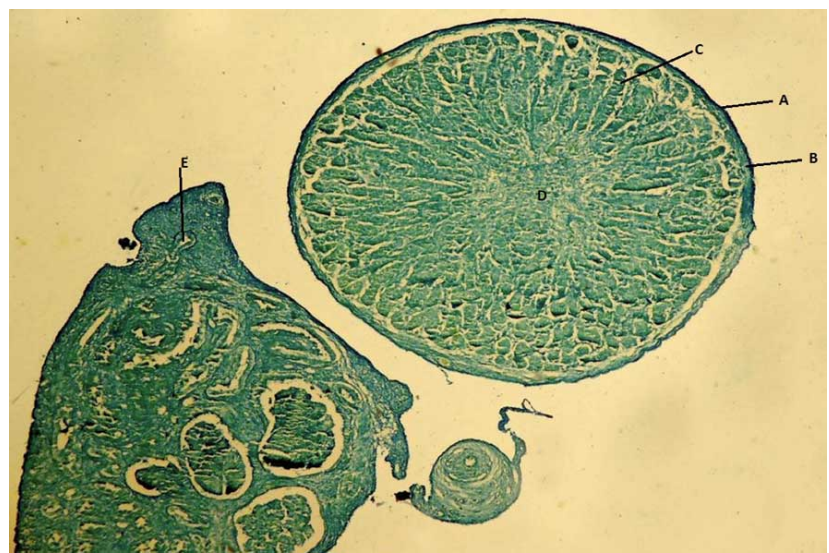

Fig. 4. Photomicrograph of testis from a 56 day old goat foetus showing acid mucopolysaccharides reaction in germinal epithelium (A), tunica albuginea (B), sex cords (C), mediastinum testis (D), and mesonephric duct (E). AMPreaction x 40.

In third group (61 to 90 days of gestation), on 65th day, the germinal epithelium was simple cuboidal and had similar characters as in group II. The cell boundaries were indiscernible. At $70^{\text {th }}$ day of gestation, the germinal epithelium was simple low cuboidal type with patches of simple squamous epithelium.
Testicular capsule (Tunica albuginea). At $44^{\text {th }}$ day of gestation, just beneath the germinal epithelium, the tunica albuginea was composed of $2-4$ layers of mesenchymal cells, fibroblasts and small capillaries (Fig.3). Mesenchymal cells had ovoid or elongated nuclei and were arranged parallel to germinal epithelium. At $48^{\text {th }}$ day of gestation, mesenchymal cells became compactly arranged in $4-6$ layers and the cells, which were close to germinal epithelium, were compressed and lied parallel to free surface. Nuclei of the mesenchymal cells were darkly stained. The inner layer contained blood capillaries indicating the beginning of the development of tunica vasculosa. At $56^{\text {th }}$ day of gestation tunica albuginea was $6-7$ cell layers thick. Moon \& Hardy (1973) reported similar views at $2.5 \mathrm{~cm}$ CRL stage pig embryos. While, Allen (1904) reported the appearance of this capsule, at $1.7 \mathrm{~cm}$ CRL stage in pig embryos. Arey (1966) observed a layer of tissue, fibrous capsule or tunica albuginea in between the germinal epithelium and testis cords at $15 \mathrm{~mm}$ CRL in human embryos. Gier \& Marion (1970) observed the appearance of the tunica albuginea at 30,33 and 41th day of gestation in horse, dog and ox, respectively. Singh et al. observed a distinct tunica albuginia at $33.5 \mathrm{~mm}$ CRL stage (47 days) in goat foeti. Goyal \& Dhingra (1973) reported that the testicular capsule contained outer thick tunica albuginea and inner thin tunica vasculosa in a day-old buffalo calves testis. In this layer along with mesenchymal cells, few large cells and differentiating RBCs were also noticed. This layer was thicker at the future caudal border of the testis than the cranial one. The reticular fibrils were noticed at 48th day of gestation in tunica albuginea, which showed primary branching at $56^{\text {th }}$ day of gestation. In II group (31 to 60 days), the average thickness of tunica fibrosa and tunica vasculosa was $17.9433+2.099$ and $12.306+1.732 \mathrm{~mm}$, respectively.

In III group (61 to 90 days), the outer thick fibrous and inner thin vascular layer could be demarcated separately. The mesenchymal cells and differentiating fibroblasts were more compactly arranged than the previous group, which were running parallel to the germinal epithelium. Inner layer contain blood vessels with erythrocytes, mesenchymal cells and reticular fibres. The average thickness of tunica fibrosa and vasculosa was $45.225+3.7124$ and $18.30+0.620 \mathrm{~mm}$, respectively. The data revealed significant increase in the thickness of the capsule as compared to group II (Table I).

In IV group (91 to 120 days), the outer layer became more fibrous. The number of blood vessels increased especially towards the caudal border of testis. The capsule became more folded, compact and compressed in configuration. Few sections showed tunica vaginalis visceralis layer containing closely packed simple squamous epithelium. The cytoplasm of these cells was highly 


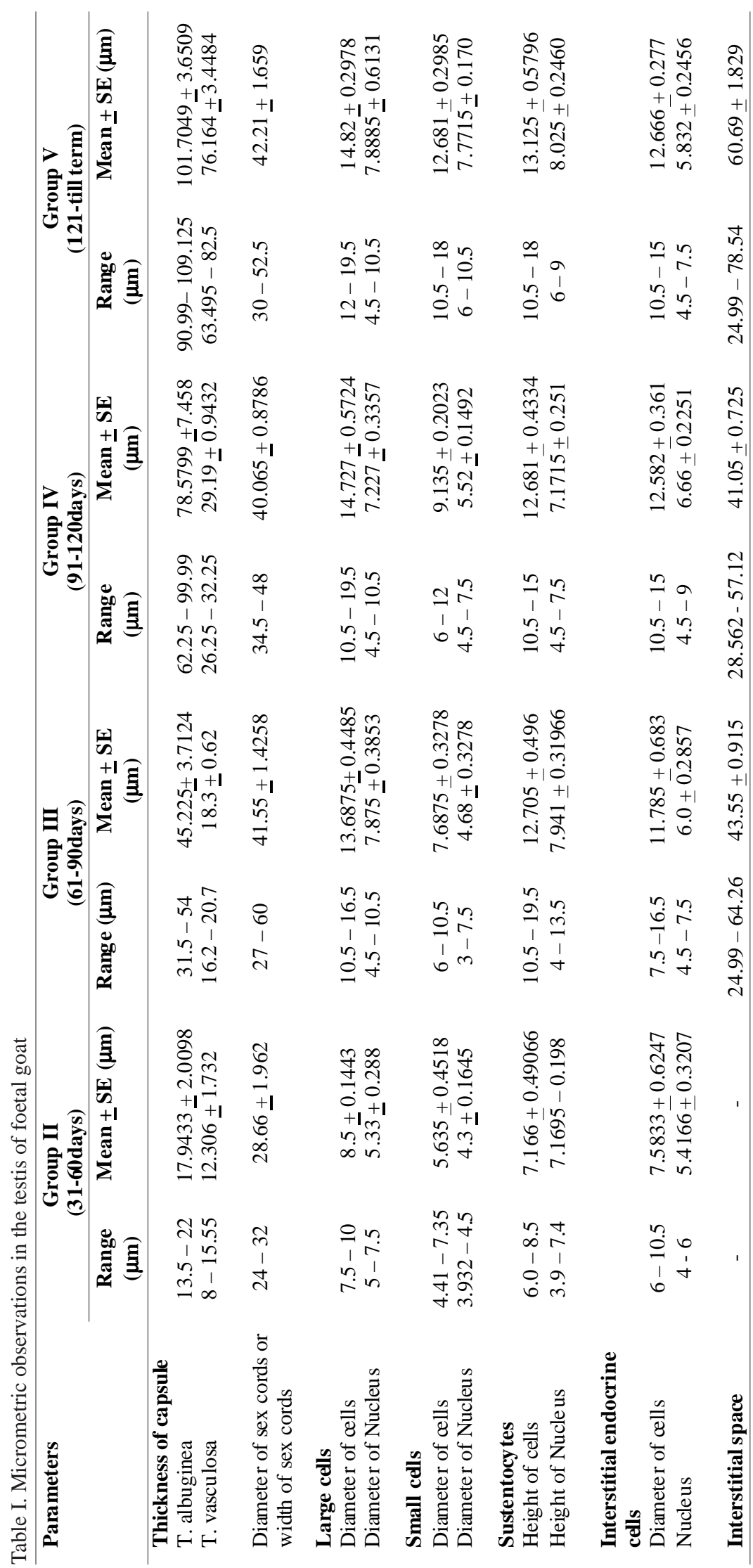

eosinophilic and showed intense reaction for PAS and acid mucopolysaccharides. The flat nuclei were darkly stained and exhibited moderate Feulgen reaction (Table II). The average thickness of tunica fibrosa and vasculosa was $78.5779+7.45$ and $29.19+0.9432 \mathrm{~mm}$, respectively (Table I).

In $\mathrm{V}$ group (121 to term), the fibrous layer was more folded and compactly arranged than that of the IV group. The collagen fibres were compactly arranged and formed bundles. There was further increase in vascularity especially towards the caudal border of the testis (Fig. 5). Fine wavy elastic fibres were encircling the lamina interna and externa of blood vessels. Endothelium of blood vessels exhibited intense PAS and moderate alkaline phosphatase reactions (Figs. 6 and 7). Tunica albuginea showed presence of lipid globules. Vascular layer showed relatively less number of lipid globules (Fig. 8, Table II).

Septula testis. At $44^{\text {th }}$ day of gestation, few mesenchymal cells from the capsule along with large cells and small blood vessels started invagination in between the developing sex cords, the septula testis (Fig. 3). At $66^{\text {th }}$ day of gestation these were observed radiating from the mediastinum testis in between the developing sex cords. These septae contained reticular fibres from 48th day of gestation. The collagen fibres appeared at 121 day onwards of gestation. The reticular fibres formed fine branching and anastomosing pattern (Fig. 9). Fine elastic fibres appeared in blood vessels in addition to collagen and reticular fibres. The connective tissue in the septula testis, showed mild to moderate reaction for PAS and moderate reaction for acid mucopoly-saccharides. These septae partially divided the parenchymya of testis into different lobules up to the full term.

Sex cords. On $44^{\text {th }}$ day of gestation, developing sex cords contained small mesenchymal and large cells arranged in a chain like manner. The large cells invaginated from the germinal epithelium (Fig.10). Singh et al., observed the process 
FAROOQUI, M. M. CHANDRAPAL, ARCHANA \& PRAKASH, A. Histological and histochemical studies on the prenatal development of testis in goat (Capra hircus). Int. J. Morphol., 30(4):1408-1421, 2012.

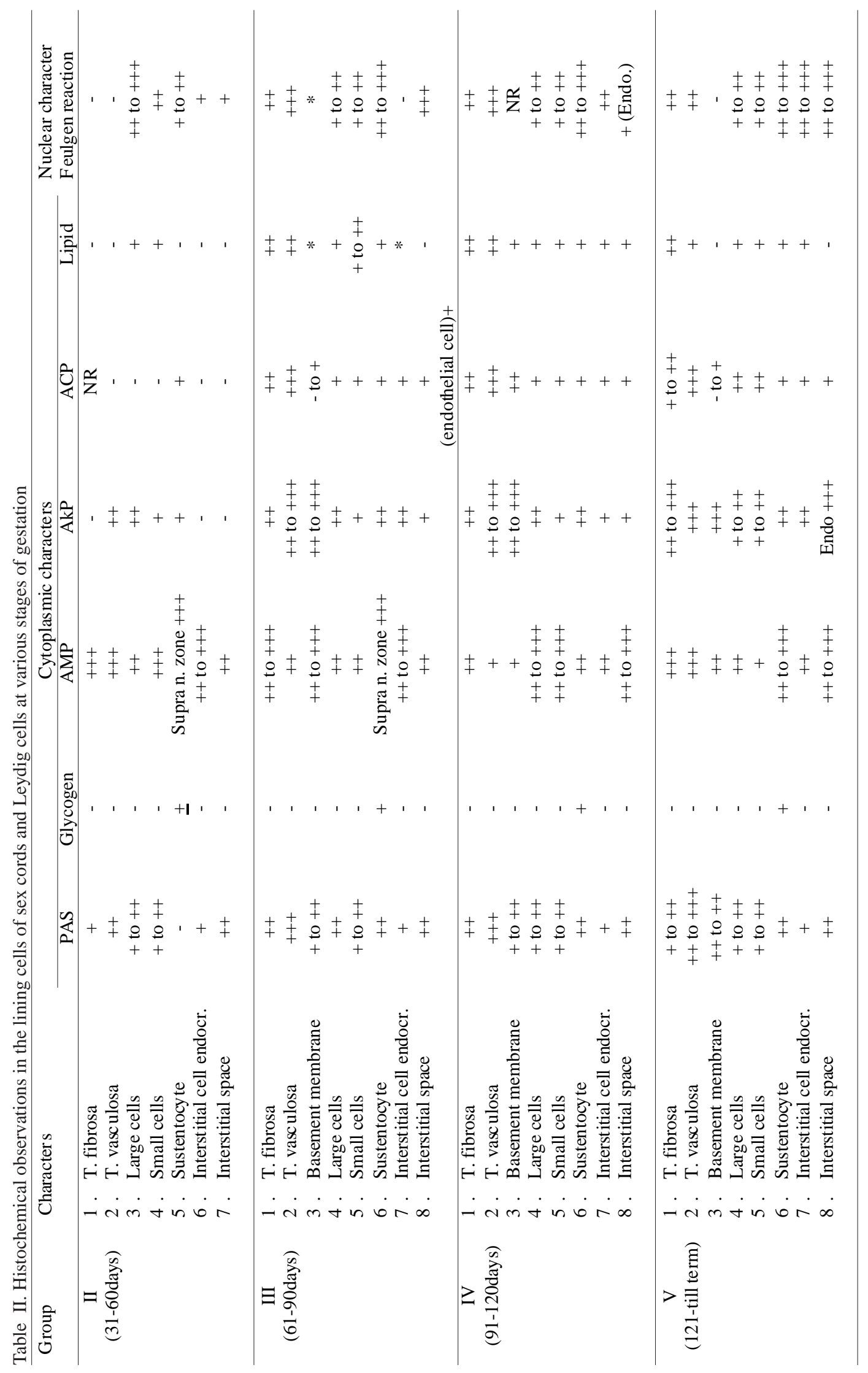




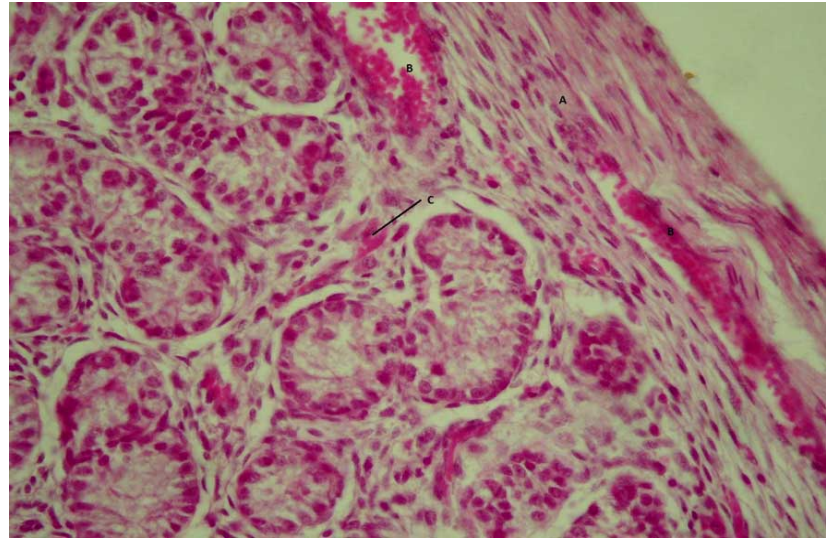

Fig. 5. Photomicrograph of testis from a 135 day old goat foetus showing fibrous layer of capsule (A), tunica vasculosa showing large blood vessel (B) and invading connective tissue septae (C). $\mathrm{H} \& \mathrm{E} x 400$.

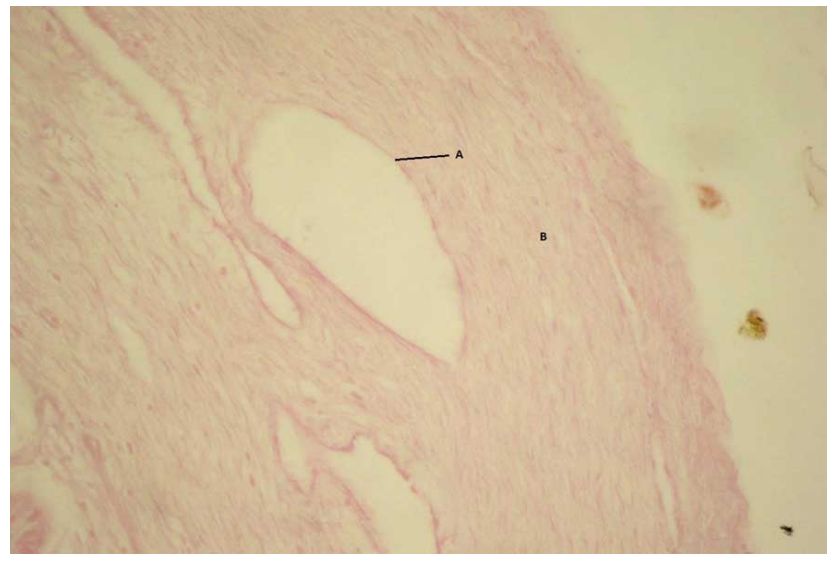

Fig. 6. Photomicrograph of testis from a 144 day old goat foetus showing intense PAS reaction in endothelium of blood vessels of capsule (A) and in fibrous layer of capsule (B). PAS x 400.

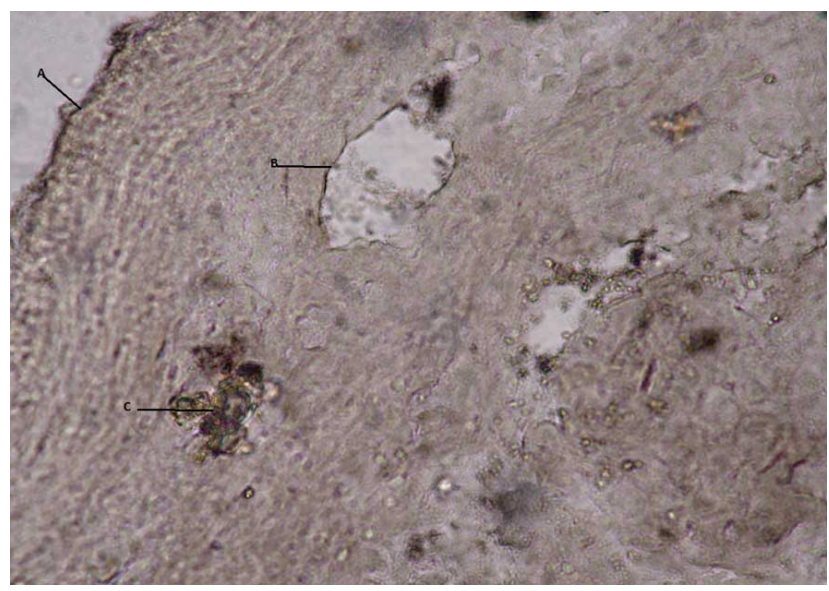

Fig. 7. Photomicrograph of testis from a 144 day old goat foetus showing intense alkaline phosphatase activity in tunica vaginalis visceralis layer (A), endothelium of blood vessels (B) and artifact (C). Modified Gomori's calcium method x 400.

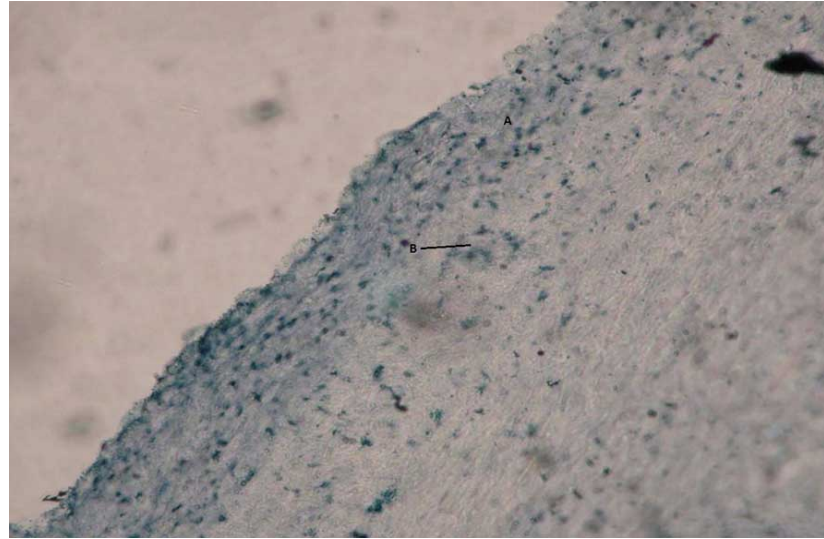

Fig. 8. Photomicrograph of testis from a 144 day old goat foetus showing presence of lipids in tunica albuginea layer (A) and blood vessels (B). Sudan Black B x 400.

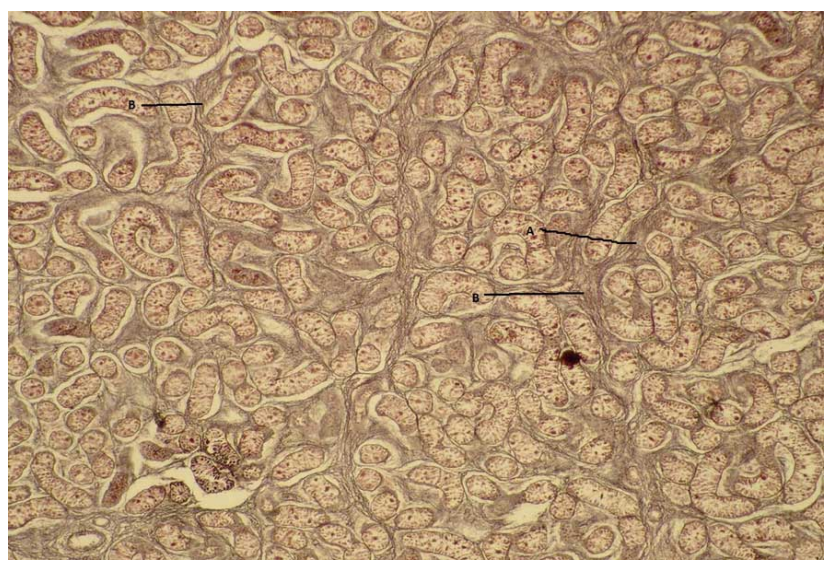

Fig. 9. Photomicrograph of testis from a 144 day old goat foetus showing reticular fibres (branching and anastomosing pattern) in Interstitial space (A) and septae (B). Wilders reticulum. Stain x 100.

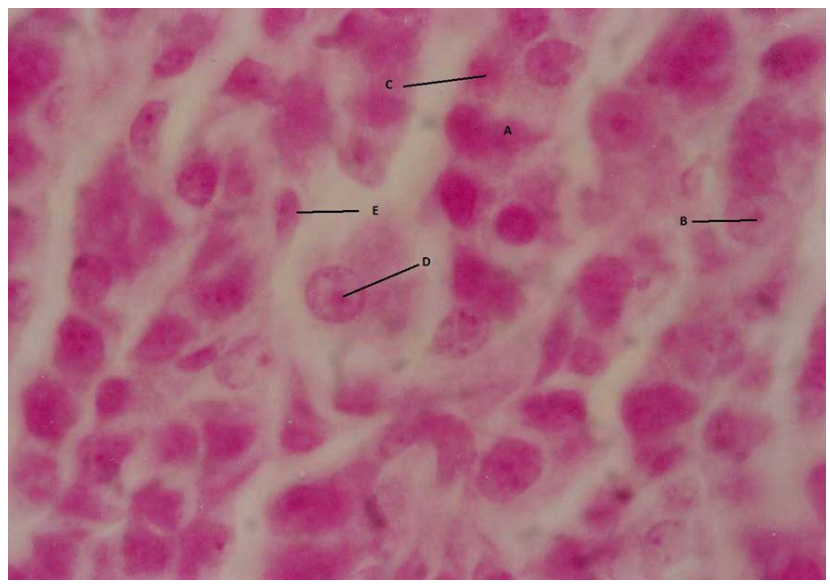

Fig. 10. Photomicrograph section of the testis from a 44 day old goat foetus showing sex cords (A), large cells (B), small cells (C), differentiating interstitial endocrine cell (D) and differentiating fibroblasts (E). H \& E x 1000. 
of formation of sex cords at $47^{\text {th }}$ day of gestation in goat foetal testis. Burns (1961) reported that the primary sex cords in amniotes proliferated from the germinal epithelium and form the medullary cords. The medullary cords developed further and became testicular cords. Several investigators used the term sex cords for seminiferous tubules until these were luminated (Hooker, 1944; Santamarina \& Reece, 1957; Abdel Raouf, 1960; Goyal \& Dhingra; Chandra Pal, 1976). The sex cords radiated towards the centre containing 1 to 3 cells in width (Fig.10). Thickness of developing sex cords increased $3-5$ cells at $48^{\text {th }}$ day of gestation. These cells grouped together to form clusters of irregular shape after a short distance from the tunica albuginia at $48^{\text {th }}$ day of intrauterine life. At $56^{\text {th }}$ day of gestation, cluster formation was further progressed. At this stage, the sex cords contained large, small and differentiating sustentocytes (Sertoli cell) (Fig.11). The basement membrane of sex cords in many of them was indistinct (Fig. 12). In few of the spherical sex cords, which were located at periphery, the basement membrane was discontinuous containing reticular fibres. Sex cords in group II contained highly eosinophilic mass in future lumen area.

In group III (61 to 90 days) at $78^{\text {th }}$ day, few sex cords located near the periphery showed slight concavity indicating the beginning of process of convolution of sex cords. The concavity was surrounded by peritubular tissue, which was comprised of differentiating fibroblasts, blood vessels, Leydig cells and mesenchymal cells. A layer of differentiating fibroblasts enveloped the developing sex cords (Fig.17). At $88^{\text {th }}$ day of gestation, the process of convolution was progressed in the sex cords located towards the centre of the parenchyma. Some peripheral sex cords became much more convolated at this stage.

In group IV (91 to 120 days), the degree of tortuousness was higher as compared to the previous group. At $116^{\text {th }}$ day of gestation and onwards, the basement membrane of convoluted sex cords was highly acidophilic and exhibited moderate to intense PAS, acid mucopolysaccharides, alkaline, and acid phosphatase reactions (Table II).

In group $\mathrm{V}$ (121 to till term), at $125^{\text {th }}$ day of gestation the process of convolution was further progressed due to which few of the sex cords appeared in the form of reverse question mark or " $\mathrm{C}$ " shaped. Upto $48^{\text {th }}$ day of gestation, the sex cords contained two types of cells viz. large and small cells. On $56^{\text {th }}$ day few small cells started differentiating into Sertoli cells (Fig. 11). Presence of large and small cells in the present study were also reported by many workers in sex cords of embryos of cattle (Santamarina \& Reece), pig (Moon \& Hardy) goat (Singh et al.), and human beings (Arey; Copenhaver et al.). The mean diameter of sex cords measured $28.66+1.962,41.55+1.4258,40.065+0.8786$ and $42.21+1.659 \mathrm{~mm}$, in group II, III, IV and V, respectively (Table I).

Large Cells. These cells were spherical or oblong in shape with distinct cell boundaries. The vacuolated cytoplasm was less eosinophilic and at places, the cell cytoplasm was almost unstained in $\mathrm{H} \& \mathrm{E}$ preparations as reported earlier by Santamarina \& Reece in buffalo foetal testis. The cytoplasm showed mild to moderate reaction for PAS and intense reaction for acid mucopolysaccharides (Fig. 4; Table II). Singh (1970) observed moderate acid mucopolysaccharides reaction in cytoplasm of large cells. The eccentrically placed vesicular nucleus of these cells was spherical or ovoid in shape. Granulated nuclear chromatin was adhering to nuclear envelopes. Similar nuclear characters were reported by Singh in the testis of foetal camel calves. These nuclei showed moderate to intense Feulgen reaction (Table II). Courot (1962) observed weak Feulgen reaction. In group II (31 to 60 days), these cells exhibited different mitotic activities and were generally placed peripherally close to basement membrane. Few cells were present towards the centre of cords. This may be an indication of the movement of the cells towards the future lumen of the cords. Singh et al., observed these cells in the centre of sex cords. The cytoplasm of large cells exhibited moderate alkaline phosphatase reaction. Lipids were present in mild concentration (Table II).

In group III (61 to 91 days of gestation), size of the cells increased abruptly. Some of these cells exhibited degenerative changes. The nucleus of the large cells was eccentrically placed and contained densely stained nucleoplasm. The average cellular and nuclear diameters of these cells were $13.6875+0.4485$ and $7.875+0.3853 \mathrm{~mm}$, respectively (Table I). At $84^{\text {th }}$ day, the large cells revealed hypertrophic and degenerative changes with more vacuolations as compared to $65^{\text {th }}$ day. At 88th day of gestation, few large cells had a vesicular, spherical nucleus with a thin rim of darkly stained cytoplasm.

In group IV (91 to 120 days), the large cells decreased in number. These cells showed degenerative changes in their nucleus. Such cells revealed pyknotic nuclei, which stained deeply as compared to group III. Few of the large cells still located close to the basement membrane and had similar characters as described in group III (61 to 90 days). Cytoplasm of most of the degenerative cells showed large sized vacuoles. The cells measured on an average $14.727+$ $0.5724 \mathrm{~mm}$ with their nuclear diameter $7.227+0.3357 \mathrm{~mm}$ (Table I). The analysis of data revealed that the diameter of cell was increased in group II afterward pyknosis of nuclei took place. 
In group $\mathrm{V}$ (121 to term) the large cell population was further decreased from 125 th day onwards. The number of degenerating cells increased (Fig.13). These cells measured on an average $14.82+0.2978 \mathrm{~mm}$ with their nuclear diameter $7.885+0.6131 \mathrm{~mm}$. Such cells contained centrally placed nucleus with densely staining chromatin granules. In this group, the nuclei of large cells showed moderate Feulgen reaction (Table II).

The degenerative changes, observed in large cells of the present study, were in agreement with Firket (1920) and Hargitt (1925) in rat, Copenhaver et al., in man, Singh et al. in goat and Baishya \& Vyas (1990) in buffalo foetal testis. These authors opined that the primordial germ cells undergo the process of degeneration with advancement of gestation. From the above observations, it appeared that the cells of the spermatogenic series had their origin from the small cells of undifferentiated stage. The present observation was in contrast to Gondos \& Conner (1973). These authors stated that in rabbit testis, the germ cells were aligned in rows at periphery of primitive tubules during last week of development. Their arrangement at this time resembled that of the spermatogonia in the adult gland.

Small cells. In group II (31 to 60 days), these cells were spherical oval or irregular in shape and were located peripherally close to the basement membrane of developing sex cords (Fig.10 and 11). These cells were compactly arranged and measured on an average $5.635+0.4518 \mathrm{~mm}$ (Table I). The cytoplasm of such cells was relatively more eosinophilic than that of the large cells. It exhibited mild to moderate reaction for PAS and intense reaction for acid mucopolysaccharides (Fig. 4, Table II). Spherical or oval nuclei of these cells contained evenly distributed, finely granular chromatin. These nuclei measured $4.3+0.1645 \mathrm{~mm}$ in diameter. These nuclei showed moderate Feulgen reaction (Table II). These cytological characters were in agreement with Santamarina \& Reece in foetal buffalo testis and Singh in foetal camel calves. The previous authors further reported that small cells formed a layer along the basement membrane in 90 days foetal buffalo testis. In the present study, distinct small cells were observed on $44^{\text {th }}$ day. Singh et al., observed these cells on $48^{\text {th }}$ day of gestation in goat foeti with similar cytological characters. The cytoplasm of small cells exhibited mild alkaline phosphatase reaction. The lipids were present in mild amount (Table II).

At $65^{\text {th }}$ day (group III) of the gestation, the small cells had similar tinctorial characters as observed in group II. At $84^{\text {th }}$ day, the nucleolus showed intense staining with eosin. Such cells within group measured $7.6875+0.3278 \mathrm{~mm}$ in diameter (Table I). Their nuclei were $4.68+0.3278 \mathrm{~mm}$ in diameter. In this group, few of the small cells were observed differentiating into Sertoli cells containing elongated nuclei with eccentric nucleolus.

In group IV (91 to 120 days), there was further increase in number of small cells than the previous group. On $116^{\text {th }}$ day, these cells had granulated eosinophilic cytoplasm. Nuclear chromatin exhibited clump formation. Few of the small cells had ovoid nucleus, which were placed horizontal to the basement membrane. The average diameter of these cells and their nuclei measured $9.135+0.2023$ and $5.52+0.1492 \mathrm{~mm}$, respectively.

In group V (121 to term) at 125th day of gestation, these cells changed their position and were situated slightly away from each other. At $135^{\text {th }}$ day, certain binucleated cells having eccentric nucleus were also noticed. Mitotic figures were present in some of these cells. At term, the cytoplasm of these cells became less eosinophilic than that of the previous groups. The average diameter of such cells and their nuclei was $12.681+0.2985$ and $7.7715+0.17 \mathrm{~mm}$, respectively. The histochemical characters of the cells were same in III, IV and V group as described in group II.

Sustentocytes (Sertoli cells). In group II (31 to 60 days), at $56^{\text {th }}$ day of gestation future sustentocytes were located among the small cells of the sex cords having a roughly pyramidal shape with indistinct cell boundaries (Fig.11). These cells were characterized by the presence of more eosinophilic cytoplasm than neighboring cells with ovoid vesicular nuclei whose long axis were directed at the right angle of basement membrane. Granulated nuclear chromatin was distributed uniformly throughout the nucleoplasm and many of the chromatin granules were present on the nuclear envelope. Gondos (1977) reported that the sustentocytes during early stages of differentiation were roughly columnar with thick cytoplasmic extension in foetal mouse. van Vorstenbosch et al. (1984) reported in pig foetal testis that until 52 days post coitum, sustentocytes changed in form during formation of sex cords, after wards their nuclei became elongated with one or more prominent nucleoli. In the present study, few of the mesenchymal cells (small cells) of sex cords differentiated into sustentocytes as reported earlier by Black \& Christensen (1969). The cytoplasm ofsustentocytes exhibited intense acid mucopolysaccharides reaction in supra nuclear zone. It exhibited mild reaction for acid and alkaline phosphatases. Turpeinen et al., (1962) also reported presence of acid phosphatase enzyme in Sertoli cells. The nuclei of the sustentocytes revealed mild Feulgen reaction (Table II).

In group III (61 to 90 days), at $65^{\text {th }}$ day of gestation, the vesicular ovoid nuclei became elongated and their coarse nuclear chromatin was distributed uniformly. Few of these cells had pyramidal nuclei. These nuclei revealed moderate 
to intense Feulgen reaction (Table II). After 70th day, the cells appeared roughly pyramidal. Few of cells showed cytoplasmic extensions from the supra nuclear zone (Fig.15). At $84^{\text {th }}$ day of gestation, these cells assumed typical pyramidal/ appearance. However, few cells had elongated nuclei. At this stage, vacuolations were slightly distinct in the infra-nuclear zone. The cytoplasm of sustentocytes exhibited moderate and intense reaction for PAS and acid mucopolysaccharides in supra nuclear zone, respectively. Glycogen and lipids were present in mild amount. The cell cytoplasm showed moderate and mild reactions for alkaline and acid phosphatase, respectively (Table II).

In group IV, at $98^{\text {th }}$ day of gestation, sustentocytes were in close contact with the basement membrane of sex cords. These cells had darkly stained eosinophilic cytoplasm in the supra nuclear zone from where the cytoplasmic extensions were going towards the future lumen (Fig.16). In this group cell cytoplasm revealed similar histochemical and histoenzymic reactions as observed in the III group (Table II). Vesicular nuclei of these cells were cylindrical or triangular in shape. The nuclear chromatin was coarsely granulated. Clumps of nuclear chromatin were observed adhering to nuclear membrane. After $116^{\text {th }}$ day of gestation, the cytological characters of the cells resembled to that of 98th day except that few nuclei contained more than one eccentrically placed nucleolus. The histochemical reactions were same as reported in the previous group. The average height of cell was $12.705+0.496,12.681+0.4334$ and $13.125+0.5796 \mathrm{~mm}$ in group III, IV and V, respectively. Their nuclei measured $7.941+0.31966,7.1715+0.251$ and $8.025+0.2460 \mathrm{~mm}$ in group III, IV and V, respectively in height (Table I).

Mediastinum testis. At $44^{\text {th }}$ day of gestation, the mediastinum testis was identifiable as an area devoid of sex cords. At $48^{\text {th }}$ day, fine reticular fibres and mesenchymal cells appeared in this area at cranio-dorsal end of the testis. At $56^{\text {th }}$ day of gestation, arterioles, differentiating spindle shaped fibroblasts with fusiform nuclei, mesenchymal cells and reticular fibres with branching pattern were distinctly visible. Singh et al., observed the analgen of mediastinum testis at 48th day of gestation in goat foetal testis.

At $65^{\text {th }}$ day of gestation, the connective tissue core of mediastinum testis grew downward where it was placed centrally. This area was poorly stained in $\mathrm{H} \& \mathrm{E}$ preparations as compared to surrounding parenchyma of the testis. Some of the mesenchymal cells of this area, located in the well vascularised zone, formed solid clusters, the forerunner of rete tubules. In subsequent stages, the branching and anastomosing pattern of reticular fibres, appearance of collagen fibres along with blood vessels and fibroblasts formed connective tissue core, which invaginated into parenchyma. Singh et al., observed similar structures at 93 days of gestation in foetal goat testis. Area of mediastinum testis showed improved staining in groups IV (91 to 120 days) and V (121 to term).

Rete tubules. At $70^{\text {th }}$ day of gestation, the rete tubules had clusters containing 5-6 cells in the area of mediastinum testis. Vacuolation were observed in the central area of developing rete tubules marking the beginning of the lumen formation. Gier \& Marion described the analgen of rete testis along the antero- lateral border of the gonadal ridge on very first day of its development. Allen observed the rete testis and the process of luminization in 10 and $13 \mathrm{~cm}$ long embryos, respectively. He observed these tubules were mainly composed of small cells, however, few large cells were also noticed. This observation was in total agreement with findings of Singh et al., Few degenerative cells with pyknotic nuclei were encountered. Small cells had indistinct boundaries at this stage. These cells possessed moderately eosinophilic cytoplasm and spherical, vesicular nuclei with uniformly distributed chromatin. Large cells contained elongated to spherical nucleus.

At $70^{\text {th }}$ day of gestation, the rete tubules had clusters containing 5-6 cells in the area of mediastinum testis. Vacuolation were observed in the central area of developing rete tubules marking the beginning of the lumen formation. Gier \& Marion described the analgen of rete testis along the antero- lateral border of the gonadal ridge on very first day of its development. Allen observed the rete testis and the process of luminization in 10 and $13 \mathrm{~cm}$ long embryos, respectively. He observed these tubules were mainly composed of small cells, however, few large cells were also noticed. This observation was in total agreement with findings of Singh et al. Few degenerative cells with pyknotic nuclei were encountered. Small cells had indistinct boundaries at this stage. These cells possessed moderately eosinophilic cytoplasm and spherical, vesicular nuclei with uniformly distributed chromatin. Large cells contained elongated to spherical nucleus.

At $78^{\text {th }}$ day of gestation, 1-2 tubules were roughly spherical got luminated and the cells started to rearrange themselves around a small lumen (Fig. 17). The epithelium appeared simple cuboidal in type. Singh et al., reported similar type of epithelium of rete tubules with indistinct cell boundaries in goat foeti.

At $84^{\text {th }}$ day of gestation, the lumen formation was further progressed. Lumen formation was observed around 93 days in goat (Singh et al.), 85 days in ox and around 45 days in dog foetuses (Gier \& Marion). Some of the tubules 


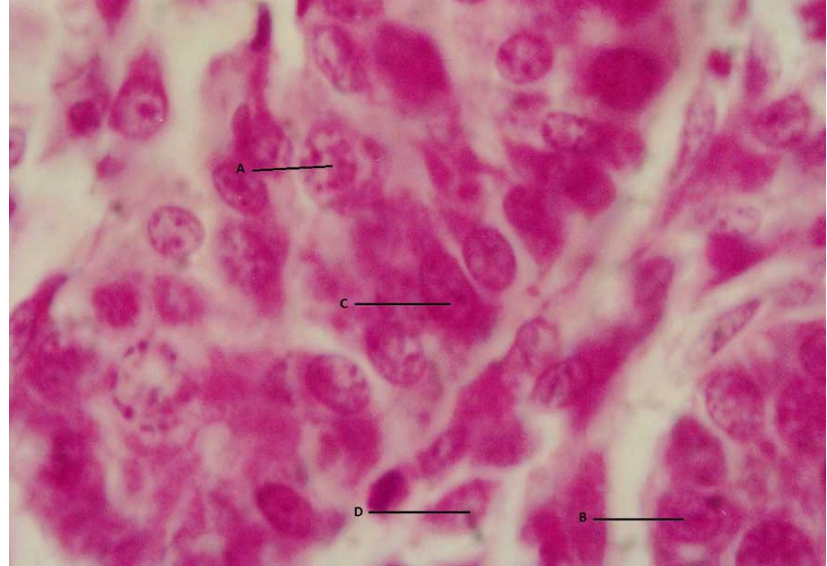

Fig. 11. Photomicrograph of testis from a 56 days old goat foetus showing the seminiferous cords with large cell (A), small cell (B), differentiating sustentocytes (C) and interstitial endocrine cell (D). $\mathrm{H} \& \mathrm{E} \times 1000$.

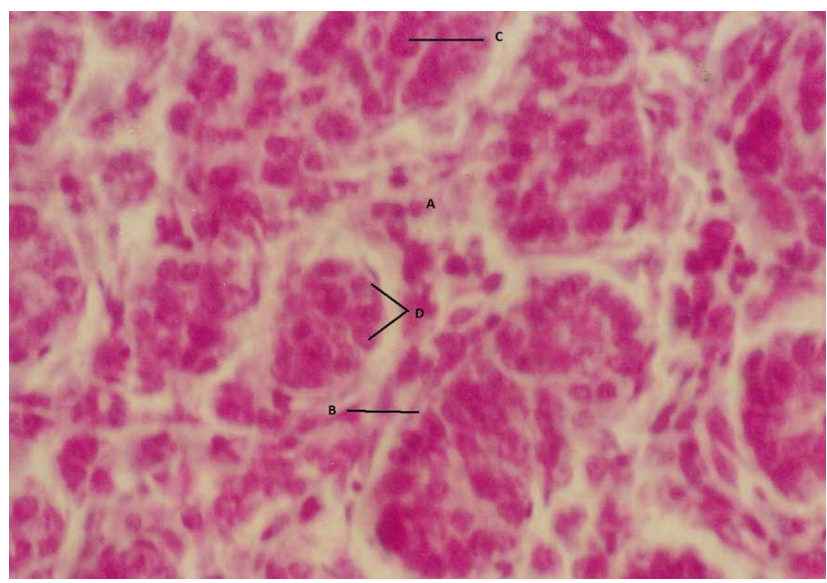

Fig. 12. Photomicrograph of testis from a 56 old goat foeti showing interstitial space in between sex cords (A), indistinct basement membrane (B), large cell (C) and small cell (D). H \& E x 200.

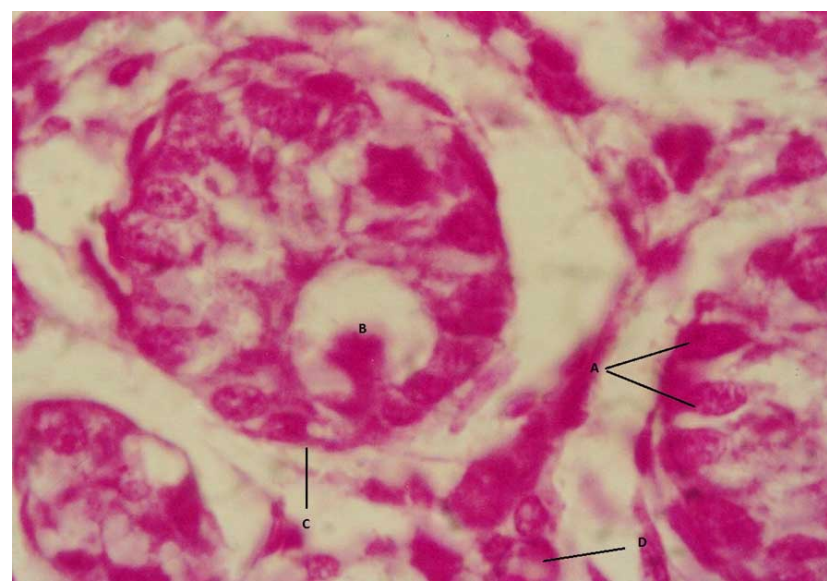

Fig. 13. Photomicrograph of testis from a 125 day old goat foetus showing sustentocytes (A), vacuolation in large cell (B), small cells (C) and interstitial cells (D). H \& E x 1000.

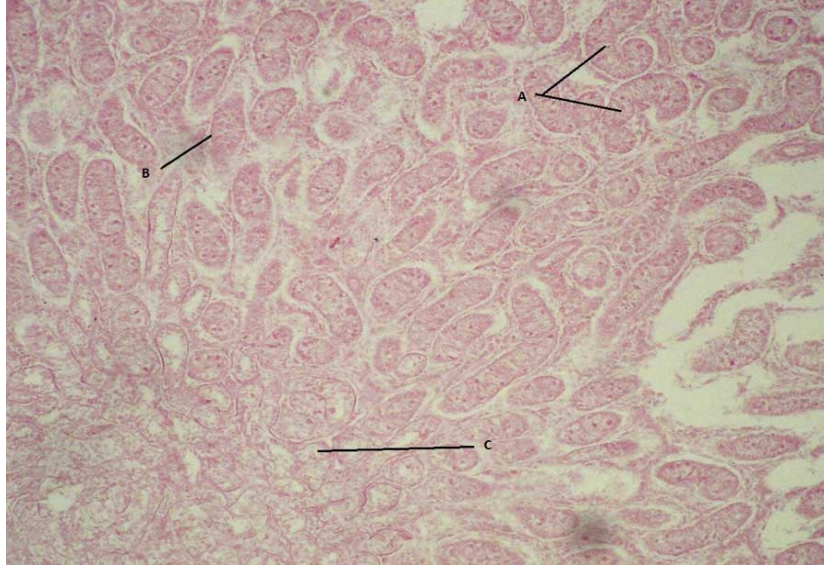

Fig. 14. Photomicrograph of testis from a 116 day old goat foetus showing PAS reaction in sex cords (A), basement membrane of sex cords (B) and basement membrane of rete tubules (C). PAS x 40.

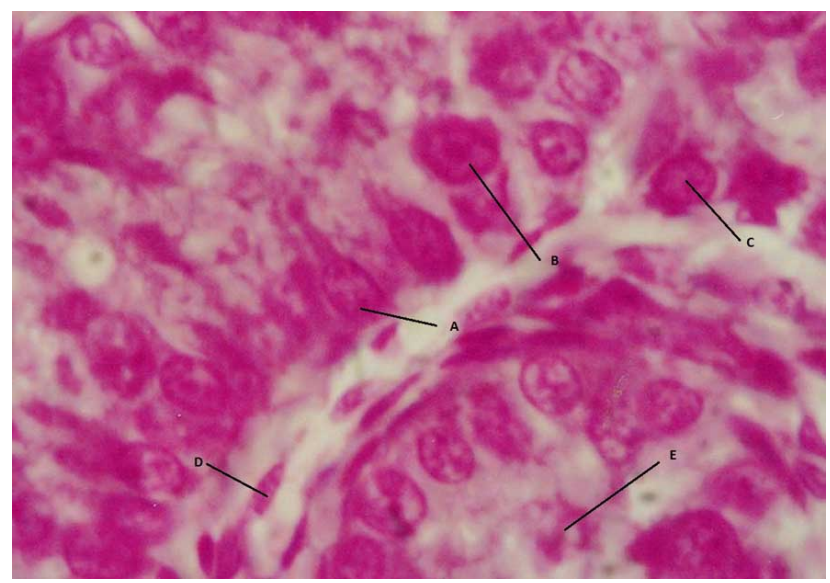

Fig. 15. Photomicrograph of testis from a 88 day old goat foetus showing sustentocytes with cytoplasmic extension (A), large cell moving towards future lumen (B), small cells (C), fibroblasts (D) and degenerating Large cell (E). H \& E x 1000.

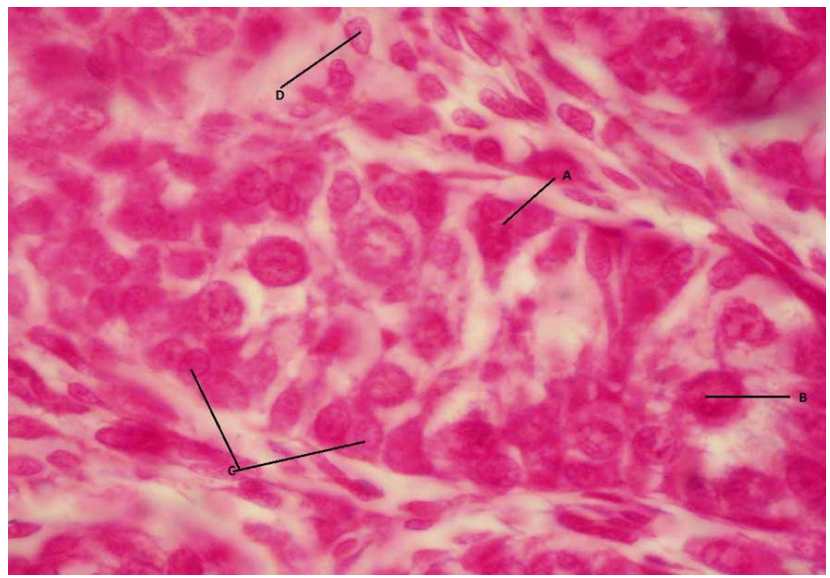

Fig. 16. Photomicrograph of testis from a 98 day old goat foetus showing sustentocytes (A), vacuolation in large cell (B), small cells (C) and interstitial cells (D). H \& E x 1000. 
may contained more than one layer of cuboidal cells. The rete tubules at this stage were surrounded by coarse reticular fibres, which had branching and anastomosing pattern. Cytoplasm of cells of rete tubules exhibited moderate acid mucopolysaccharides reaction (Fig. 18). The basement membrane of rete tubule showed intense PAS reaction (Fig. 14). Cytoplasm of small cells exhibited mild to moderate PAS reaction.

In $\mathrm{V}$ group (121 to term), on $135^{\text {th }}$ day, most of the rete tubules were luminised. This observation was in full agreement with the observations of Singh et al., in foetal goat testis. The cytoplasm of the small cells was relatively less eosinophilic. At this stage lumen contained still eosinophilic mass. Few of these rete tubules were observed making connections with tubuli recti. A layer of darkly stained fibroblasts, elastic, collagen and coarse reticular fibres covered the rete tubules (Fig. 19, 9 and 20).

Straight tubules / tubuli recti . In III group (61 to 90 days) at 65th day of gestation, the lower portion of few of the radially directed, solid sex cords near the rete tubules began to form the future tubuli recti. These were incompletely invested by fine fibres along with fibroblasts. At 88th day of gestation, these tubules were making connections with rete tubules. Solid straight tubules were mainly composed of small cells with indiscernible boundaries. The terminal part of such tubules started canalization leading to beginning of the lumen formation. The basement membrane of such tubules showed intense PAS reaction while small cells cytoplasm showed mild to moderate reaction.

At 102 day of gestation, the tubuli recti and rete tubules connections were further progressed. Singh et al., also observed such connections at 115 days. Simple cuboidal to columnar epithelium lined these tubules. The cytoplasm of these cells was moderately eosinophilic. The nuclei were spherical and vesicular in nature. Few cells showed vacuolations. At this stage, the lumen was not completely formed; as upper portion of recti tubules were still solid.

In $\mathrm{V}$ group, the tubuli recti exhibited similar characters as in group IV. The lumen formation occurred in few tubules, which further progressed after 115 day. These tubules had simple cuboidal epithelium. The basement membranes contained reticular and wavy collagen fibres, which showed intense PAS reaction. Fine elastic fibres were noticed in the basement membrane of these tubules at 144th day of gestation (Fig. 20). The basement membrane of the tubules showed intense alkaline phosphatase activities (Fig. 21).
Interstitial space. The spaces between developing sex cords were comprised of mesenchymal cells, differentiating fibroblasts reticular fibres, capillaries and Interstitial endocrine cells at 44 days onwards (Fig.10). In later stages of gestation, the reticular fibres showed branching and anastomsing pattern (Fig. 9), spindle shaped fibroblasts, blood vessels, nerves and collagen fibres (Fig. 19). The interstitial endocrine cells were distributed singly or in groups. The contents of interstitial space showed moderate reaction for PAS and acid mucopolysaccharides. Endothelium of blood vessels showed intense and mild alkaline and acid phosphatase reactions, respectively. Nuclei of the fibroblasts and mesenchymal cells revealed intense Feulgen reactions (Table II).

Interstitial endocrine cells (Leydig cells). At $44^{\text {th }}$ day of gestation, few of the mesenchymal cells, located in between the sex cords, started developing into future Interstitial endocrine cells, characterized by their roughly polygonal shape and highly eosinophilic cytoplasm. The spherical nuclei of these cells were vesicular in character and contained a distinct eccentrically placed nucleolus. At this stage, these cells were present singly (Fig. 10). The origin of interstitial endocrine cells from the interstitial mesenchymal cells was reported in cattle (Santamarina \& Reece; Gier \& Marion), dog (Gier \& Marion) and pig (Black \& Christensen; Moon \& Hardy). In the present study, differentiation of interstitial endocrine cells started after the appearance of tunica albuginea, which was the characteristic feature of gonadal differentiation. Moon \& Hardy in pig and Singh et al., in goat reported similar views. However, Singh et al., observed interstitial endocrine cells differentiation at $47^{\text {th }}$ day in goat foetal testis.

At 56th day of foetal life, interstitial endocrine cells were present in groups of 2-3 cells along with differentiating fibroblasts. These cells were usually located near the differentiating capillaries (Fig.11). Gondos \& Conner reported that these cells appeared in pairs and groups around interstitial blood vessels during the last 3 days of gestation in hamster testis. Singh reported similar views in foetal camel calves testis. Baishya \& Vyas (1990) reported similar views in foetal buffalo testis regarding presence of blood vessels and progressive increase in number of interstitial endocrine cells as the age of foetus advanced. Guraya (1980) found an increased of testosterone production with the corresponding increased in number of interstitial endocrine cells. Similar opinion was also expressed by Hooker (1970), who further contradicted the same stating that the type of interstitial endocrine cells rather than total number was a significant consideration. Therefore, in view of present study, it could be opined that steriodogenesis might have started around $56^{\text {th }}$ day of intra uterine life onwards in goat foetal testis. 


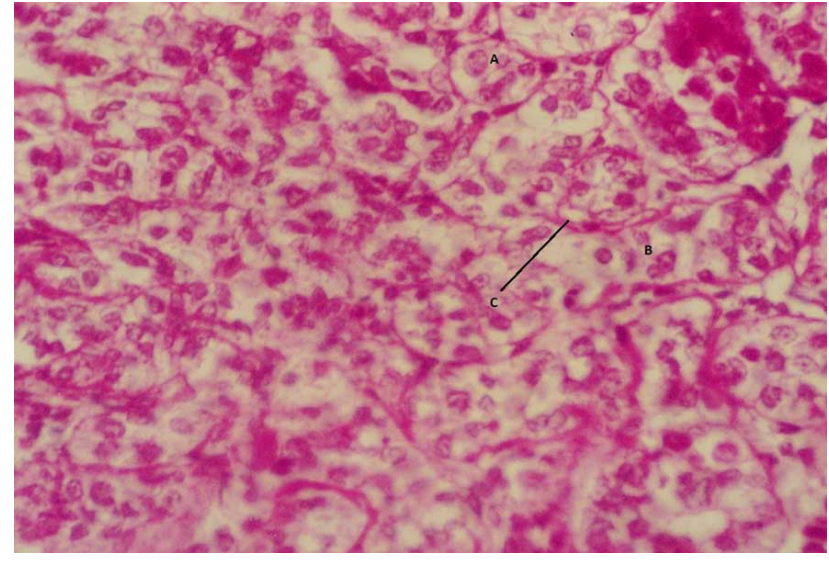

Fig. 17. Photomicrograph of testis from a 78 day old goat foetus showing the developing rete tubules on the verge of formation of lumen (A), future tubuli recti (B) and basement membrane (C). $\mathrm{H}$ \& E x 400 .

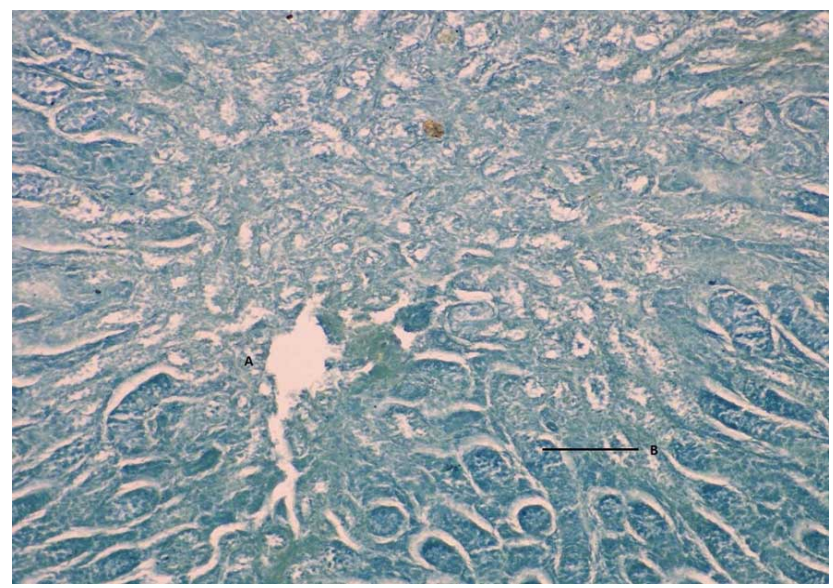

Fig. 18. Photomicrograph of testis from a 88 day old goat foetus showing AMP reaction in rete tubules (A) and cells of sex cords (B). AMP reaction $\mathrm{x} 100$.

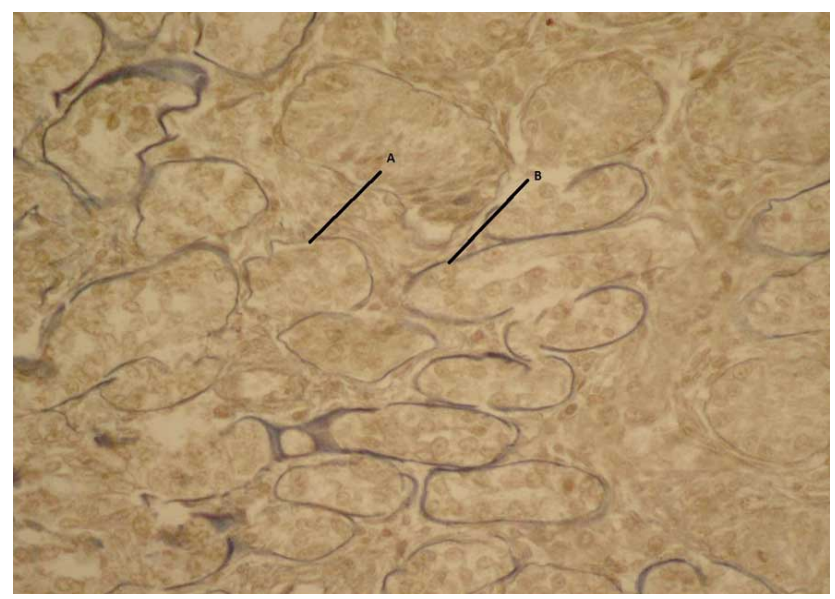

Fig. 19. Photomicrograph of testis from a 121 day old goat foetus showing collagen fibres in basement membrane of rete tubules (A), and tubuli recti (B). Mallory's triple stain x 400 .

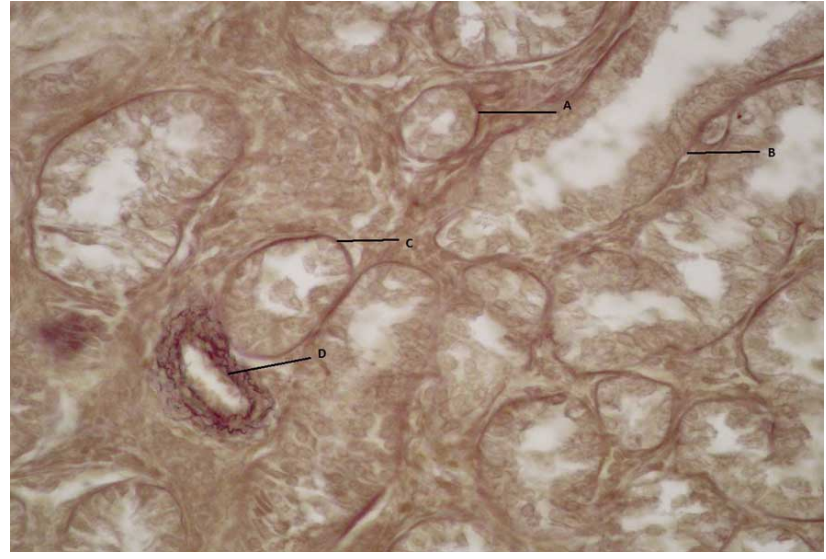

Fig. 20. Photomicrograph of testis from a 144 day old goat foetus showing elastic fibres around basement membrane of rete tubules (A), tubuli recti (B), centrally placed sex cords (C) and blood vessels (D). Weigert's Resorcin Fuchsin Elastic Stain x 400.

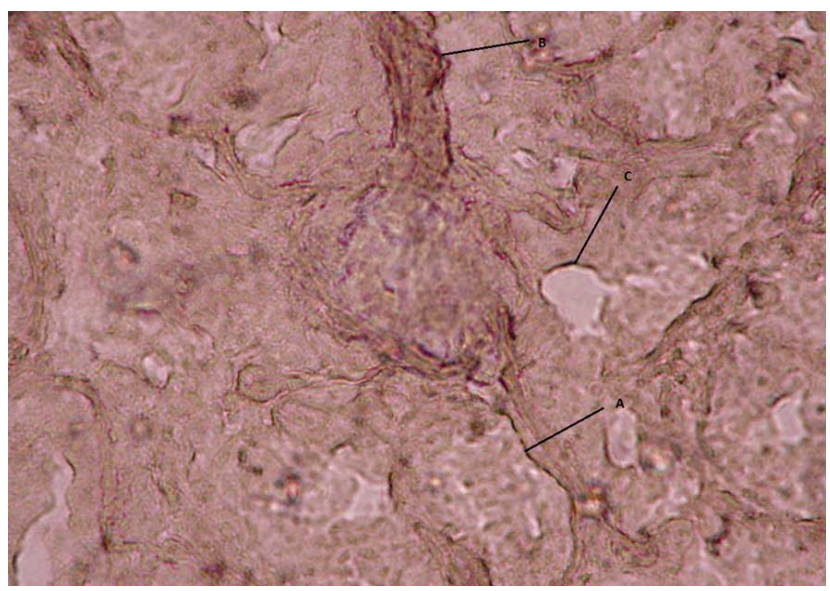

Fig. 21. Photomicrograph of testis from a 144 day old goat foetus showing intense alkaline phosphatase activity in basement membrane of sex cords (A), tubuli recti (B) and endothelium of blood vessels (C). Modified Gomori's calcium method x 400.

FAROOQUI, M. M. CHANDRAPAL, ARCHANA \& PRAKASH, A. Estudios histológicos e histoquímicos del desarrollo prenatal del testículo de cabra (Capra hircus). Int. J. Morphol., 30(4):1408-1421, 2012.

RESUMEN: El estudio se basó en el desarrollo prenatal de testículosde de 70 embriones / fetos de cabra, clasificados en el grupo I (0-30 días), Grupo-II (31-60 días), Grupo III-(61-90 días), grupo IV (91 a 120 días) y el grupo V (121 días-hasta el nacimiento), con 14 embriones / fetos en cada grupo. La cresta genital se observó a los 23 días de gestación. Contenía una acumulación de células mesenquimales inmaduras de RBC, fibroblastos de diferenciación y células germinales primordiales. La formación de los cordones sexuales se puso de manifiesto en el día 44 de gestación. Contenía pequeñas células mesenquimales y células grandes dispuestas en cadena. La convolución de los cordones sexuales se 
inició entre 61-90 días de gestación, que se incrementaron con el aumento en el período de gestación, a los 125 días de gestación pocos cordones sexuales alcanzaron la forma de signo de interrogación inversa. Los sustentocitos se observaron entre las pequeñas células de los cordones sexuales en el día 56 de gestación. La túnica albugínea apareció justo debajo del epitelio germinal en el día 44 de gestación. Se componía de 2-4 capas de células mesenquimáticas, fibroblastos y capilares pequeños. El espesor de la túnica albugínea aumentó con el avance en la edad del feto y entre 61-90 días de gestación, la capa fibrosa gruesa exterior y la capa interior delgada vascular podría ser demarcadas por separado. Pocas células mesenquimales inician diferenciación en los endocrinocitos intesticiales localizadas en los espacios intersticiales en el día 44 de gestación.

Cabra.

PALABRAS CLAVE: Testículos; Desarrollo prenatal;

\section{REFERENCES}

Abdel-Raouf, M. The postnatal development of the reproductive organs in the bulls with special reference to puberty (including growth of hypophysis and adrenal). Acta. Endocr. Copenhagen, Supp. 49: 109, 1960.

Allen, B. M. The embryonic development of the ovary and testis of the mammals. Am. J. Anat., 3:89-153, 1904.

Archana, P. Correlative anatomy of testis, epididymis and accessory sex glands in Gaddi goat. Ph.D Thesis. Submitted to Pt. DDU Pashu Chikitsa Vigyan Vishvavidayalaya Evam Go Anusandhan Sansthan (DUVASU)- Mathura, 2006.

Arey, L. B. Developmental Anatomy - A text book and laboratory manual of embryology. $7^{\text {th }}$ ed. Philadelphia and London,W.B. Saunders Company, 1966.

Baishya, G. \& Vyas, K. N. Histomorphological development of foetal testis in the Surti buffalo. Indian J. Anim. Sci., 60(12):1425-30, 1990.

Baishya, G.; Ahmed, S. \& Bhattacharya, M. Development of testes in Assam goat (Capra hircus). Indian Vet. J. 64:24-8, 1987.

Bancroft, J. D. \& Stevens, A. Theory and practice of histological technique. New York, Churchill Livingston, 1971.

Black, V. H. \& Christensen, A. K. Differentiation of interstitial cells and Sertoli cells in foetal guniea pig testis. Am. J. of Anat., 124:211-38, 1969.

Burns, R. K. Role of hormones in the differentiation of sex. In: Sex and internal secretions. Ed. by W.C. Young, Baltimore, M. D., Williams and Wilkins, 1961. pp. 76-160.
Chandra Pal Gross, histological and histochemical studies on male genital system of buffalo (Bubalus bubalis). Ph.D. thesis, submitted to Agra University, Agra, 1976.

Copenhaver, W. M.; Kelly, D. E. \& Wood, R. L. Bailey's Text Book of Histology. $17^{\text {th }}$ ed. Baltimore, The Williams and Wilkins Company, 1978.

Courot, M. Development du testicule chez l'agneau. Estabissment de la spermatogenese. Ann. Biol. Animale, Biochem. Biophys., 2:25, 1962 .

Crossman, G. A. A modification of Mallory's connective tissue stain with discussion of principles involved. Anat. Rec., 69: 33-8, 1937.

Davenport, H. A. Histological and histochemical technics. Philadelphia, W. B. Saunders Company, 1960.

Firket, J. On the origin of germ cells in higher vertebrates. Anat. Rec., 18:309-16, 1920.

Gier, H. T. \& Marion, G. B. Development of mammalian testis. In: The testis. Johnson, A.J.; Gomes, W.R.; \& Vandemark, N.L. (Eds.), New York Academic Press, 1970. Vol. I. pp. 2-43.

Gondos, B. The testis. Johson, A. D., Gomes, W. R. \& Vandemark, N. L. (Eds.). New York, Academic Press, 1977. Vol. IV, pp. $1-27$.

Gondos, B. \& Conner, L.A. Ultrastructure of developing germ cells in the foetal rabbit testis. Am. J. Anat., 136:23-42, 1973.

Goyal, H. O. \& Dhingra, L. D. A study on post-natal histology of the testis in buffalo (Bubalus bubalis). 1. From birth to one year. Acta. Anat., 84(2):237-50, 1973.

Gupta, A. N. Correlative Anatomy of the testes, epididymis \& accessory sex glands in goat. Ph.D Thesis, HAU Hisar, 1989.

Guraya, S. S. Recent progress in the morphology, histochemistry, biochemistry and physiology of developing and maturing mammalian testis. Int. Rev. Cytol., 62:188-306, 1980.

Hargitt, G. T. The formation of the sex glands and germ cells of mammals. I. The origin of germ cells in the Albino rat. $J$. Morphol., 40:517-58, 1925.

Harvey, E. B. Aging and foetal development. In: Reproduction in Domestic Animals Cole, H. H. \& Eupps, P.T. (Eds.). 1st ed., New York, Academic Press Inc., 1959. Vol. I. pp. 461-6.

Hooker, C. W. The postnatal histology and function of the interstitial cells of the testis of the bull. Am. J. Anat., 74:1$37,1944$.

Hooker, C. W. The intertubular tissue of the testis. In : The testis. Johnson, A. D., Gomes, W. R. \& Vandemark, N. L. (Eds.), Academic Press, New York, 1970. Vol. I. 
FAROOQUI, M. M. CHANDRAPAL, ARCHANA \& PRAKASH, A. Histological and histochemical studies on the prenatal development of testis in goat (Capra hircus). Int. J. Morphol., 30(4):1408-1421, 2012.

Hugget, A. St. G. \& Widdas, W.F. The relationship between mammalian foetal weight and conception age. J. Physiol., 114:306-17, 1951.

Islam, M. N.; Hossain-M. I.; Quasem, M. A. Postnatal development of testis, epididymis and ductus deferens in Black bengal goats. Bangladesh Veterinarian, 19:129-38, 2002.

Johnson, A. D.; Gomes, W. R. \& Vandemark, L.N. The testis. $1^{\text {st }}$ ed., New York, Academic Press, 1970. Vol. 1.

Luna, L. G. Manual of histological staining methods of the Armed Forces Institute of Pathology. $3^{\text {rd }}$ ed. New York, The Blakistan Division, Mc-Graw Hill Book Company, 1968.

Moon, Y. S. \& Hardy, M. H. The early differentiation of the testis and interstitial cells in the foetal pig and its duplication in organ culture. Am. J. Anat., 138:253-68, 1973.

Patten, B. M. Embryology of the Pig. New York, McGraw Hill Book Company, 1948. pp. 211.

Santamarina, H. \& Reece, R. P. Normal development of the germinal epithelium and seminiferous tubules in the bull. Am. J. Vet. Res., 18:261-78, 1957.

Singh, U. B. Gross, hostological and certain histochemical observation on the testis and poll gland of camel (Camelus dromadarius) during different phases of sexual cycle. Ph.D. thesis University of Udaipur, Udaipur, 1970.

Singh, Y.; Sharma, D. N. \& Dhingra, L. D. Morphogenesis of the testis in goat. Indian J. Anim. Sci., 49(11):925-31, 1979.

Turpeinen, P.; Turpeinenl, O. \& Talanti, S. Effect of local heat in vivo on hyaluronidase, succinic dehydrogenase and phosphatase of the rat testis. Endocrinology, 70:731, 1962. (Cited by Johnson et al., 1970).

van Vorstenbosch, C. J.; Spek. B. Colenbrander, B. \& Wensing, C. J. Sertoli cell development of pig testis in the foetal and neonatal period. Biol. Reprod., 31:565-77, 1984.
Correspondence to:

M.M. Farooqui

Pt. Deen Dayal Upadhyaya Veterinary University-

Mathura

INDIA

E-mail: pathak_arcvik@yahoo.com

Received: 14-02-2012

Accepted: 14-05-2012 